Islamijah: Journal of Islamic Social Sciences

Vol. 1,No.3 (2020), pp. 272-288, Doi : 10.30821/islamijah.v1i3.8764

\title{
SEKOLAH TINGGI ISLAM: Latar Belakang dan Perkembangan
}

\author{
Maisyaroh \\ Universitas Islam Negeri Sumatera Utara Medan \\ Jl. Willem Iskandar Pasar V Medan Estate, 20371 \\ e-mail: syarohmai38@gmail.com
}

\begin{abstract}
This article examines the background and development of Sekolah Tinggi Islam, abbreviated as STI. This study is important and interesting considering that STI is the first Islamic higher education institution established by Muslim leaders in Indonesia. Not many studies have been conducted in this institution. This study followed a literature study and used a historical approach in collecting the data. The data were then analyzed using the content analysis method. The findings of this study indicate that STI is the first Islamic university in Indonesia which was first led by Abdul Kahar Muzakkir. Several Muslim leaders also contributed in the establishment of this Islamic campus, namely: Mohammad Hatta, A. Wahid Hasyim and Mas Mansur. The campus curriculum follows the al-Azhar University curriculum. STI has two departments, namely: Religious Science and Public Science. STI was later converted into the Islamic University of Indonesia, abbreviated as UII. The conversion of STI to UII is based on efforts to fulfill the demand of the ummah for a higher education institution that is able to integrate general knowledge and Islamic teachings. This study is expected to contribute to the historical study of Islamic education in Indonesia.
\end{abstract}

Keywords: history, higher education, Sekolah Tinggi Islam 
Islamijah: Journal of Islamic Social Sciences, Volume 1, Number 3, September 2020: 272-288

\section{Pendahuluan}

Para pembaharu di Indonesia pada pertengahan abad ke-20 menaruh perhatian terhadap pendidikan. Setelah madrasah dan pesantren berkembang sedemikian rupa, para pembaharu tersebut mulai memikirkan pendirian perguruan tinggi Islam. Organisasi-organisasi Indonesia melalui wadah Masyumi mempelopori pendirian perguruan tinggi Islam. Pada tanggal 8 Juli 1945 atas inisiatif para pemimpin Muslim dan didukung oleh organisasi-organisasi Islam didirikanlah Sekolah Tinggi Islam, disingkat STI. Usaha ini kemudian membuatkan hasil, bahkan diikuti oleh sejumlah organisasi Islam seperti Muhammadiyah dan Nahdlatul Ulama di Jawa, bahkan Al Jam'iyatul Washliyah di Sumatera (Ja'far, 2016; 2019). Sekelompok tokoh juga mendirikan perguruan tinggi misalnya Universitas Islam Sumatera Utara (UISU) di Medan. Pasca kemerdekaan, sejumlah pemuka dan organisasi Islam mendirikan perguruan tinggi yang bercorak Islam.

Secara umum artikel ini mengkaji historisitas Sekolah Tinggi Islam. Secara khusus, studi ini menjawab dua pertanyaan (1) bagaimana latar belakang pendirian STI? (2) Bagaimana perkembangan STI di masa berikutnya?. Berdasarkan dua rumusan tersebut, studi ini bertujuan untuk menelaah latar belakang dan perkembangan STI. Studi ini penting dilakukan mengingat sedikit sekali kajian historis yang diterbitkan di jurnal ilmiah mengenai lembaga pendidikan tinggi ini. Studi ini menggunakan pendekatan historis. Sebagai sebuah studi kepustakaan, studi ini memanfaatkan sumber-sumber tertulis mengenai objek yang ditelaah. Sumbersumber tertulis tersebut akan dikaji dengan metode analisis isi. Data kemudian direduksi, dipaparkan dan kemudian dilakukan penarikan kesimpulan.

\section{Sekolah Tinggi Islam di Jakarta}

Sekolah Tinggi Islam (disingkat STI) merupakan pendidikan tinggi Islam yang pertama di Indonesia. Berdirinya STI ini berbeda dengan latar belakang berdirinya sekolah tinggi umum. Sekolah tinggi umum berdiri tidak didesak oleh kebutuhan terhadap lanjutan pelajaran. Akan tetapi berdirinya perguruan tinggi umum lebih dilatarbelakangi oleh kebutuhan terhadap pegawai yang berpendidikan tinggi, kurangnya ahli atau pekerja yang memiliki pendidikan 
tinggi disebabkan putusnya hubungan dengan Belanda selama Perang Dunia I, sehingga baik pemerintah dan perusahaan di bidang industri mengalami kesukaran mencari pegawai berpendidikan tinggi dan perusahaan-perusahaan tidak berfungsi secara maksimal dengan baik. Pada saat itu, bangsa Indonesia membutuhkan perguruan tinggi sendiri sebagai wadah untuk meningkatkan kehidupan intelektual di Indonesia (Nasution, 1995: 1).

Sementara itu, Sekolah Tinggi Islam (STI) berdiri karena tuntutan banyaknya alumni pesantren atau madrasah pada tingkat menengah atas yang tidak dapat melanjutkan ke jenjang perguruan tinggi Islam. Pada masa kolonial Belanda, umat Islam di Indonesia belum memiliki perguruan tinggi Islam. Sementara untuk alumni sekolah Belanda atau sekolah umum, setelah tamat dari jenjang sekolah menengah atas, mereka bisa melanjutkan ke lembaga pendidikan tinggi umum misalnya Sekolah Tinggi Tekhnik (Technische Hoge School) yang berdiri pada tahun 1920 di Bandung, Sekolah Tinggi Hukum (Rechts Hoge School) yang berdiri di Bandung pada tahun 1920, kemudian Sekolah Tinggi Kedokteran (Geneeskundige Hoge School) yang didirikan oleh Belanda pada tahun 1927 di Jakarta. Dengan demikian, lembaga pendidikan tinggi umum di Indonesia didirikan oleh Belanda, dan kebijakan tersebut lebih dipengaruhi Aufklarung dan politik etik. Hal lain yang patut mendapat perhatian adalah bahwa hanya kaum elit bangsa Indonesia yang bisa menjadi mahasiswa di perguruan tinggi yang didirikan Belanda (Daulay, 2014: 124). Alumni madrasah atau pesantren tidak mungkin diterima di perguruan tinggi tersebut. Kendati sikap yang tidak demokratis demikian, atau adanya penyekatan-penyekatan sehingga membuat masyarakat Indonesia khususnya organisasi-organisasi Islam dan tokoh-tokoh pendidikan Islam memutuskan untuk mendirikan sebuah lembaga pendidikan tinggi Islam sehingga generasi muda yang berasal dari pesantren atau madrasah bisa melanjutkan pelajaran mereka dan memperoleh ilmu yang lebih tinggi lagi.

Sejumlah alumni madrasah dan pesantren, untuk melanjutkan pendidikan mereka, menempuh studi keagamaan di luar Indonesia, khususnya di Saudi Arabia, Mesir dan juga India. Para pelajar yang menempuh sekolah di sana berbaur dengan siswa dari segala penjuru dunia. Mereka memperoleh ilmu pengetahuan dan saling bertukar pikiran. Pada awal-awal abad ke-20, banyak 
pelajar dari Indonesia, karena ketiadaan perguruan tinggi Islam di Indonesia, melanjutkan pendidikan mereka ke Universitas al-Azhar. Banyak dari mereka ikut memperjuangkan kemerdekaan dan melawan Belanda. Di antara mereka adalah Muchtar Luthfi, Iljaz Jakub, Djamaluddin Thaib, Djamaluddin Ibrahim, Rasuna Said, Chatib Suleiman, Darwis Thaib, atau Leon Salim (Kahin, 2005: 105).

Dalam konteks Sumatera Utara, beberapa pelajar agama menempuh pendidikan di luar Indonesia. Di antaranya adalah Ismail Banda dimana pada tahun 1936, ia mulai kuliah di Universitas al-Azhar, Mesir dan memperoleh gelar S1 pada tahun 1940. Kemudian, pada tahun 1942, ia menyelesaikan S2 atau Master of Arts (M.A) (Ja'far, 2020). Kemudian diikuti oleh Adnan Lubis yang menempuh pendidikan sekolah di Madrasah Shaulatiyah di Makkah dan tamat pada tahun 1932. Dua tahun kemudian, ia mendapatkan beasiswa untuk melanjutkan studi di perguruan tinggi di India, yakni di Al-Jami'ah Darul Ulum Nadwatul Ulama, dan ia kemudian pada tahun 1939 pulang ke Indonesia (Thaib \& Hasballah, 2017). Beberapa ulama seperti Hasan Maksum, Yusuf Ahmad Lubis, Abdurrahman Sjihab dan M. Arsjad Th. Lubis pernah belajar di Haramain, meskipun sebagian dari mereka hanya belajar sebentar saat menunaikan ibadah haji (Ja'far, 2020). Mereka menempuh pendidikan di luar negeri dan kembali ke Indonesia dengan membawa segudang ilmu yang diperoleh dari luar negeri. Mereka kemudian berusaha melakukan pembaharuan dalam bidang pendidikan.

Sebenarnya ide mendirikan perguruan tinggi Islam sudah muncul sebelum Indonesia merdeka. Pada tanggal 2-7 Mei 1939, organisasi-organisasi Islam di Indonesia mengadakan Kongres Al-Islam ke-II di Solo. Kongres ini secara khusus diinisiasi oleh Majelis Islam A'la Indonesia (MIAI) yang dihadiri sebanyak 25 organisasi Islam. Dalam pertemuan tersebut, Dr. Satiman pertama kali menyerukan keinginannya dan keinginan masyarakat Muslim untuk mendirikan sebuah perguruan tinggi. Dengan keputusan bersama, akhirnya forum Kongres AlIslam menyepakati dan menghasilkan tiga program yang akan dirancang, salah satu di antaranya ialah mendukung untuk mendirikan pendidikan tinggi Islam di Indonesia (Salahuddin, 2014). Meskipun susunan rancangan telah dibuat, namun sampai pada akhir penjajahan Belanda, pendirian pendidikan tinggi 
belumlah terealisasikan sesuai dengan yang diinginkan (Mochtar: 2003). Pecahnya perang dunia ke-II dan masuknya Jepang ke Indonesia menambah pengaruh yang tidak baik terhadap perencanaan pendirian pendidikan tinggi Islam di Indonesia. Karena pada masa itu, Jepang sama sekali tidak mengizinkan adanya pendidikan tinggi. Pihak Jepang hanya mengizinkan membuka sekolah untuk tingkat dasar dan menengah (Daulay, 2014).

Namun semangat yang ada pada generasi muda dan organisasi Islam untuk mendirikan pendidikan tinggi Islam di Indonesia tidaklah surut. Kemudian usaha ini dilanjutkan kembali oleh Masyumi. Sejak Indonesia di bawah jajahan Jepang (1942-1945), seluruh seluruh partai Islam dibubarkan kecuali empat organisasi yang bergabung dalam MIAI, yaitu Nahdlatul Ulama, Muhammadiyah, PUI (di Majelengka), dan PUII (di Sukabumi). Keempat organisasi tersebut bergabung dalam satu tempat yaitu Masyumi yang merupakan penjelmaan baru dari pada MIAI. Kemudian Masyumi mengadakan rapat. Dalam sebuah artikel yang berjudul "Sejarah Singkat Fakultas Hukum UII" disebutkan bahwa rapat menghasilkan dua keputusan penting. "Pertama, membentuk sebuah barisan mujahidin dengan nama Hizbullah untuk berjuang melawan sekutu bersama-sama dengan pemerintahan Jepang untuk mewujudkan kemakmuran bersama di Asia Timur Raya. Kedua, mendirikan perguruan tinggi Islam dengan nama Sekolah Tinggi Islam (STI)." Sebagai bentuk realisasi dari keputusan yang telah disepakati dalam rapat sebelumnya, dan semangat yang tidak pantang menyerah dalam mendirikan perguruan tinggi Islam di kalangan umat Islam, Masyumi sebagai gabungan dari berbagai organisasi Islam berhasil mempelopori pendirian perguruan tinggi Islam pertama di Indonesia.

Pada bulan April 1945, para pemimpin kaum Muslim mengadakan rapat kembali di Jakarta dan mengundang para ulama dan cendekiawan dari berbagai kalangan swasta dan pemerintahan untuk lebih merealisasikan keinginan itu. Rapat tersebut dihadiri oleh tokoh-tokoh organisasi Islam yang menjadi anggota dari Masyumi. Mereka di antaranya:

1. K.H. Abdul Wahab Chasbullah, K.H. Bisri Syamsuri, K.H. A. Wahid Hasyim, K.H. Masykur, dan K.H. Zainal Arifin dari PBNU. 
2. Ki Bagus Hadikusumo, K.H. Mas Mansur, K.H. Hasyim, K.H. Farid Ma'ruf, K.H.Abdul Mukti, K.H.M. Yunus Anis, dan Kertosudarmodari PBMuhammadiyah.

3. K.H. A. Halim dan H. Muhammad Djunaidi Mansur dari PB PUI.

4. K.H. Ahmad Sanusi dan K.H. Somaatmadja dari PB PUII.

5. K.H. Imam Ghazali dari PB Al-Islam.

6. K.H. A. Kahar Muzakir, K.H.R. Mohammad Adnan, dan K.H. Imam Zarkasji dari Shumubu.

7. Dr. Soekiman Wirjosandojo, Dr. Satiman Wirjosandjojo, Wondoamiseno, Abikusno Tjokrosujoso dan Mohamad Roem dari kalangan cendekiawan (Harjono \& Hakim, 1997; Daulay, 2014).

Adapun struktur kepanitian pembentukan Panitia Perencana STI sebagaimana disebut oleh Harjono \& Hakim (1997) sebagai berikut:

Ketua : Drs. Mohammad Hatta

Wakil Ketua : Mr. Soewandi

Sekretaris : Dr. Ahmad Ramali

Anggota $\quad$ : K.H. Mansur, K.H.A. Wahid Hasjim, K.H.R. Fatchurrahman Kafrawi, K.H. Farid Ma'ruf, K.H. Abdul Kahar Muzakkir

Notulis : Kartosoedarmo

Sejumlah sumber menunjukkan bahwa kehadiran tokoh-tokoh di atas dinilai sudah mewakili para tokoh Muslim di Indonesia. Peristiwa bersejarah ini diberitakan oleh harian Sinar Matahari yang beralamat di Jalan Tugu 58 Yogyakarta dengan judul "Pendirian Sekolah Tinggi Islam di Djawa." Setelah melakukan rapat berulang kali, akhirnya Panitia Perencana menetapkan (1) menyusun Peraturan Umum, (2) menyusun Peraturan Rumah Tangga, (3) menetapkan susunan Badan Wakaf Pendiri STI, (4) menetapkan Badan Penyelenggara dan Pengawas STI, dan (5) menetapkan Senat STI (Harjono \& Hakim, 1997: 7).

Berkat perjuangan para tokoh Muslim di atas, akhirnya atas bantuan dari pemerintahan Jepang Sekolah Tinggi Islam (STI) secara resmi dibuka pada tanggal 8 Juli 1945 di Jakarta atau 27 Rajab 1364 H. yang bertepatan dengan 
peringatan Israk Mikraj Nabi Muhammad Saw. Dipilihnya tanggal tersebut sebagai tanggal peresmian dengan harapan STI mendapatkan tafa' ul (berlanjut dengan kebaikan-kebaikan) pada masa-masa selanjutnya. Peresmiannya diadakan di Gedung Kantor Imigrasi Pusat Gondangdia Jakarta yang dihadiri sejumlah pembesar Jepang, pemimpin Kenkoku Gakuin, pimpinan Jakarta Ika Daigaku, serta sejumlah tokoh pergerakan nasional (Tashadi, 1986). Pada acara peresmian tersebut Soekarno dan Rektor STI, K.H. Abdul Kahar Muzakkir, diminta untuk menyampaikan pidato. Dalam pidatonya, Presiden Soekarno mengharapkan STI kelak bisa menjadi pusat pengetahuan keislaman di Asia. Begitu juga dengan K.H. Abdul Kahar Muzakkir yang menyampaikan betapa pentingnya pendidikan menurut ajaran Islam (Nakamura: 2019; Harjono \& Hakim, 1997). Dalam hal ini, keinginan Masyumi dalam mendirikan STI lebih beruntung mendapatkan dukungan dari Jepang, karena mereka memiliki kedekatan dengan Jepang karena organisasi Masyumi (Majelis Syura Muslimin Indonesia) adalah organisasi yang dibentuk oleh Jepang pada tahun 1943 dengan tujuan untuk mengendalikan umat Islam di Indonesia, berbeda dengan MIAI yang sering mendapatkan tekanan dari pihak Jepang (Fathoni: 2018). Dukungan yang diberikan oleh Jepang dalam mendirikan pendidikan tinggi Islam merupakan salah satu bentuk penunaian janji yang selama ini menjanjikan dukungan kemerdekaan kepada rakyat Indonesia. Pendirian STI merupakan bentuk realisasi Jepang untuk mendapat dukungan dari kalangan Muslim.

STI berdiri berbeda dengan berdirinya ketiga sekolah tinggi yang sebelumnya didirikan oleh perintah Belanda. Technische Hoge School (Sekolah Tinggi Teknik), Rechts Hoge School (Sekolah Tinggi Hukum), Geneeskundige Hoge School (Sekolah Tinggi Kedokteran) berdiri karena pelaksanaan politik Belanda "balas budi". Sedangkan STI murni dari gagasan dan para pemimpin umat Islam (Harjono \& Hakim, 1997).

Sebagai ketua dalam perencana, Mohammad Hatta berpendapat bahwa STI harus benar-benar bisa melebihi bahkan menyaingi sekolah tinggi yang didirikan oleh Jepang. Sekolah Tinggi Hukum yang didirikan oleh Jepang memiliki lama pelajarannya hanya 2 tahun saja. Menurutnya, 2 tahun dalam menempuh pendidikan untuk jenjang sekolah tinggi dalam mendapatkan pelajaran belumlah 
maksimal. Oleh karenanya, ia berinisiatif untuk proses lamanya belajar di STI harus 5 tahun, sebagai tindak lanjut dari idenya Hatta merundingkan hal tersebut kepada pemerintah Jepang, dan menghasilkan putusan bahwa untuk mahasiswa yang lulusan dari STI harus menjalani lamanya pelajaran 4 tahun. Dua tahun tingkat kandidat dan dua tahun tingkat doktoral (Harjono \& Hakim, 1997).

Adapun susunan kelengkapan organisasi STI sebagaimana disebut Harjono \& Hakim (1997) adalah:

Pengurus Badan Wakaf

Ketua $\quad$ : Said Wiratman Hasan

Wakil Ketua/Bendahara : Sutan Sabaruddin

Sekretaris : Kartosoedarmo

Anggota-anggota :

K.H. Hasyim Asy'ari, Ki Bagus Hadikusumo, K.H. Abdul Halim Iskandar, K.H. Ahmad Sanusi, K. Abu Ansor, K. Hamid, Dr. Satiman Wirjosandjojo, Dr. Soekiman Wirjosandjojo, Hasan Arghubi, Djohan Djohar, Aly bin Arief. H. Bilal, M. Prawirosemito dan Salim Nabhan.

Dewan Pengurus/ Kurator STI:

Ketua : Dr. Mohammad Hatta

Wakil Ketua : Mr. Soewandi

Sekretaris : Mohammad Natsir

Anggota : Prof. R.A.A. Hoesein Djajadiningrat, Dr. Hidajat, Dr. Soekiman Wirjosandjojo, Baginda H. Dahlan Abdullah, Abikoesono dan H. Rahman Tamin.

Senat STI

Rektor Magnificus : K.H. Abdul Kahar Muzakkir

Anggota-anggota :

K.H. Mas Mansur, Prof. Dr. Poerbotjaroko, Prof. Dr. Slamet Iman Santoso, 
Mr. Sumanang, Mr. Abdul Karim, Mr. Ali Budiardjo, Mr. Moh. Yamin, Mr. Kasman Singodimedjo, Prof. Mr. Sunarjo Kolopaking, Dr. A. Ramali, Drs. Adam Bachtiar, Ustadz Sadeli Hasan, K.M. Zein Djambek, dan ditambah beberapa orang guru Sekolah Menengah Tinggi di Jakarta sebagai asisten.

Staf Sekretaris :

Sekretaris : : Mohammad Natsir

Wakil Sekretaris : Prawoto Mangkusasmito

Bendahara $\quad$ : A. Zaenuddin (Harjono dan Hakim, 1997).

Selanjutnya untuk penerimaan mahasiswa, STI terlebih dahulu melakukan penyeleksian alumni antara lain sebagai berikut. Pertama, tamatan Algemene Middelbare School (AMS) dan Hogere Burger School (HBS) 5 tahun, Hollands Inlandse Kweekshool (HIK), Sekolah Menengah Tinggi (SMT), dan yang sederajat. Kedua, tamatan Madrasah Menengah Tinggi yang mempunyai pengetahuan umum setingkat dengan Sekolah Menengah Umum (Harjono \& Hakim, 1997).

Untuk jumlah mahasiswanya, STI berhasil mendapatkan 14 orang dari 78 peserta yang mendaftar. Sebanyak 11 pelajar berasal dari Sekolah Menengah Hindia Belanda AMS (Algemene Middelbare School), atau HBS (Hogere Burger School) dan sederajat, 3 orang berasal dari Madrasah Aliyah. 64 orang masuk ke jenjang matrikulasi selama satu atau dua tahun. Kemudian baru boleh melanjutkan ke STI (Daulay, 2014). Matrikulasi diberikan kepada pendaftar yang berasal dari sekolah menengah Hindia-Belanda. Mereka diberikan tambahan ilmu pengetahuan bahasa Arab dan pengetahuan Agama. Kemudian, bagi alumni Madrasah Aliyah, mereka diberikan pengetahuan yang bersifat umum (Daulay, 2006). Adapun mereka yang diterima di STI baik tingkat permulaan maupun persiapan antara lain adalah Bachroem Rangkoeti, Djanamar Adjam, M. Sjarwani, Achmad Buchari, Ahmad Nasuhi, Anwar Harjono, Muhammad Djanu, A. Moechtar, Bermawi Said, Macmoed Idie, Adnan Sjamni, Zainal Abidin, Hasjim, Masmimar, Makah, Makmoer Harun, Darsjaf Rachmar, A. Karim Halim, Siti Rahma Djajaningrat, Abo Rachmat, M. Dimjati, Bagdja Natadiwirja, Soeroto, Soebinti, Djojohadikoesoemo, Soeroto Koento, Maisaroh Hilal, dan Soebagijo Ilham Notodidjojo (Harjono \& Hakim, 1997). 
Selanjutnya, untuk kurikulum atau rancangan pembelajaran, STI menggunakan kurikulum Fakultas Ushuluddin Universitas al-Azhar Kairo. Kurikulum ini jauh berbeda dengan kurikulum pada sekolah dan perguruan tinggi umum. Semua sekolah dan perguruan tinggi umum memasukkan bahasa dan kebudayaan Jepang sebagai pelajaran wajib. Di STI justru tidak ada mata kuliah tersebut. STI mengikuti kurikulum di Universitas al-Azhar, Kairo. STI hanya memiliki dua jurusan: Ilmu Agama dan Ilmu kemasyarakatan (Ahmad, 2010: 136).

Adapun tujuan awal didirikan STI ini adalah memberikan pelatihan dan lanjutan pendidikan kepada pelajar atau orang-orang yang telah memperoleh pendidikan Islam secara meluas dan mendalam di lembaga pendidikan tingkat sekolah, seperti yang dituntut oleh masyarakat, sehingga menghasilkan alumni yang memiliki pendidikan tinggi dalam bidang agama dan kemasyarakatan agar menjadi seorang penyiar agama dan memberikan pengaruh-pengaruh Islam di Indonesia (Bachtiar, 2018: 35). Pendirian STI tidak hanya menjadi tumpuan harapan bagi pemuda dalam mengembangkan ilmu pengetahuan, akan tetapi juga STI menjadi sebuah lembaga perguruan tinggi yang menjadi alternatif bagi mereka sebagai mahasiswa yang tidak mau ditekan oleh pemerintah Jepang (Harjono \& Hakim, 1997).

Empat puluh hari setelah STI berdiri, cita-cita seluruh bangsa Indonesia selama era penjajahan menjadi kenyataan. Pada tanggal 17 Agustus 1945, bangsa Indonesia meraih kemerdekaan. Dalam fase persiapan kemerdekaan, banyak dari tokoh pendiri STI yang ikut terlibat dalam mempersiapkan kemerdekaan Indonesia (terutama dalam Badan Penyelidik Usaha-usaha Persiapan Kemerdekaan Indonesia, atau BPUPKI). Tentu saja, mereka berperan sebagai founding fathers Republik Indonesia. Banyak dari pendiri STI yang menjadi pemimpin setelah Indonesia merdeka seperti menjadi Wakil Presiden, Menteri dan Perdana Menteri, sembari juga bertugas sebagai tim pendidik di STI. Beberapa bulan kemudian, wilayah Indonesia diduduki Tentara Sekutu (NICA) dengan tujuan membawa kepentingan Belanda yang ingin kembali menjajah Indonesia setelah Jepang menyerah. 
Kemudian terjadi pertempuran antara Tentara Sekutu dan rakyat Indonesia. Gedung-gedung yang ada di Jakarta berhasil dikuasai oleh Sekutu, sehingga Jakarta yang merupakan tempat STI berdiri juga harus merasakan dampak serangan yang dilakukan Tentara Sekutu. Kondisi yang terjadi di ibukota tersebut akhirnya tidak memungkinkan STI melakukan kegiatan perkuliahan, karena tidak adanya jaminan keamanan bagi civitas akademika STI. Kampus ini kemudian ditutup untuk sementara waktu. Hal ini merupakan langkah dan keputusan yang diambil oleh pimpinan STI kala itu. Serangan Tentara Sekutu inilah yang menyebabkan pemerintah Republik Indonesia harus mengambil keputusan untuk memindahkan ibukota Indonesia dari Jakarta ke Yogyakarta (Triyadi, 2009: 111-112).

\section{Sekolah Tinggi Islam di Yogyakarta}

Kedatangan Tentara Sekutu di Indonesia mengakibatkan STI pindah dari Jakarta ke Yogyakarta. Tepat pada tanggal 10 April 1946, STI kembali dibuka di Yogyakarta, yang dihadiri oleh Presiden Soekarno dan Wakil Presiden Mohammad Hatta, serta pejabat tinggi negara lainnya baik dari sipil maupun militer (Salahuddin, 2014). Menurut Haidar, dalam acara pembukaan kembali STI di Yogyakarta, Mohammad Hatta menyampaikan sebuah pidato yang berjudul "SifatSekolah Tinggi Islam." Selanjutnya, K.H. Hadjid juga berkontribusi menyampaikan pidato (kuliah umum) tentang Ilmu Tauhid (Daulay, 2014). Pembukaan ini dilakukan di Ndalem Pengulon Yogyakarta (Triyadi, 2009).

Untuk sementara, gedung STI di Yogyakarta berada di Jalan Secodiningratan I (Kamil, 1999). Adapun rektor yang memimpin STI di Yogyakarta ini adalah Abdul Kahar Muzakkir, akan tetapi terdapat perubahan kelengkapan anggota Senat STI. Untuk kelanjutan jurusan dan kurikulum tetap tidak mengalami perubahan yaitu memiliki dua jurusan, yaitu Ilmu Agama dan Ilmu Masyarakat sebagai wujud untuk melatih ulama-ulama yang dapat memahami ilmu agama

dengan baik sekaligus memiliki standar pengetahuan yang memadai. Kurikulum STI masih mengikuti kurikulum Universitas al-Azhar, Kairo (Bachtiar, 2018: 35). 
Islamijah: Journal of Islamic Social Sciences, Volume 1, Number 3, September 2020: 272-288

\section{Konversi STI menjadi UII}

Universitas Islam Indonesia (UII) merupakan universitas Islam tertua yang terletak di Yogyakarta. Perkembangan STI menjadi UII sebenarnya lebih dilatarbelakangi sebagai bentuk memenuhi permintaan terhadap sebuah lembaga pendidikan tinggi yang mampu mengintegrasikan pengetahuan umum dengan ajaran Islam (Pulungan, 2019: 359-360). Selanjutnya, timbul keinginan di kalangan tokoh umat Muslim untuk mengembangkan efektivitas dan fungsi STI. Muncul sebuah gagasan baru dari para pendiri maupun tokoh dalam melakukan perubahan STI menjadi sebuah Universitas Islam Indonesia (UII). Tepatnya pada bulan November 1947, dibentuklah sebuah komite yang dipimpin oleh KHR. Fatchurrahman Kafrawi dan KH. Farid Ma'ruf. Dalam sebuah tulisan (lihat dalam http:// www.almujtaba.com) disebutkan faktor yang mendorong perubahan STI menjadi UII. Pertama, ditinjau dari segi ajaran Islam, tidak ada pemisahan antara paham kenegaraan dan agama. Kedua, adanya kewajiban bagi umat Islam untuk melaksanakan perintah Allah. Ketiga, belum ada perguruan tinggi yang berdasarkan Islam dan mampu menyiapkan tenaga ahli di berbagai lapangan. Keempat, pada masa kolonial, pendidikan diadakan hanya untuk menjamin kepentingan pihak penjajah. Pada masa kemerdekaan, pendidikan diperlukan untuk memfasilitasi kepentingan nasional. Kelima, dinilai perlu memberikan kesempatan kepada para pelajar madrasah dan pesantren untuk melanjutkan studi ke perguruan tinggi yang memberikan ilmu-ilmu keahlian (praktis kemasyarakatan).

Adapun visi dan misi UII sebagai sebuah lembaga pendidikan tinggi memiliki hakikat yang sama dengan STI, yaitu mencetak para sarjana Muslim yang siap mengisi dan membangun Negara Republik Indonesia dengan rida dan ampunan Allah Swt. Hal ini terlihat dalam visi dan misi yang dapat dilihat dalam situs resmi UII:

Visi UII: "terwujudnya Universitas Islam Indonesia sebagai rahmatan lil 'alamin, memiliki komitmen pada kesempurnaan (keunggulan), risalah islamiah, di bidang pendidikan, penelitian, pengabdian masyarakat dan dakwah, setingkat universitas yang berkualitas di negara-negara maju." Misi UII adalah "menegakkan wahyu Ilahi dan sunah Nabi sebagai sumber kebenaran mutlak serta rahmat bagi alam semesta, dan mendukung cita-cita luhur dan suci bangsa Indonesia dalam mencerdaskan kehidupan bangsa 
melalui upaya membentuk tenaga ahli dan sarjana muslim yang bertakwa, berakhlak, terampil, berilmu amaliah dan beramal ilmiah, mengembangkan dan menyebarluaskan ilmu pengetahuan, teknologi, seni yang berjiwa agama Islam, membangun masyarakat dan negara Republik Indonesia yang adil dan makmur berdasarkan Pancasila dan Undang-Undang Dasar 1945 yang diridai oleh Allah Swt, serta mendalami, mengembangkan, dan menyebarluaskan pemahaman ajaran agama Islam untuk dihayati dan diamalkan oleh warga Universitas dan masyarakat pada umumnya." (lihat dalam https:// www.uii.ac.id/profil).

Dalam sebuah artikel disebutkan bahwa K.H. Farid Ma'ruf menyatakan bahwa UII adalah kelanjutan dari STI yang didirikan beberapa pemimpin Islam, termasuk Dr. Mohammad Hatta. Proses perubahan STI menjadi UII didahului dengan pembukaan Kelas Pendahuluan (Pra Universitas). Kelas Pendahuluan tersebut diresmikan pada bulan Maret 1948 di Pendopo nDalem BPH Purbojo, Ngasem, Yogyakarta. Adapun pembukaan UII secara resmi diadakan pada tanggal 27 Rajab 1367/10 Maret 1948 di Pendopo Dalem Kepatihan, Yogyakarta. Acara peresmian ini dihadiri oleh sejumlah Menteri Negara, pejabat sipil dan pejabat militer (Harjono \& Hakim, 1997: 14-19).

Pada tahap awal konversi STI menjadi UII, didirikan empat fakultas, yakni Fakultas Agama, Fakultas Hukum, Fakultas Pendidikan dan Fakultas Ekonomi. Lokasi setiap fakultas berbeda-beda. Kampus terpadu berada di Jalan Kaliurang KM. 14,5, Kabupaten Sleman. Fakultas Ekonomi berada di Jalan Ringroad Utara Condongeatur Kabupaten Sleman. Fakultas Hukum berada di Jalan Tamansiswa Yogyakarta (Pulungan, 2019: 359). Kurikulum UII tidak jauh berbeda dari kurikulum sebelumnya yang mengikuti kurikulum Universitas al-Azhar, Kairo (Bachtiar: 2018).

Kampus UII mulai beraktivitas pada bulan Juni 1948. Setelah tujuh bulan mengadakan kegiatan perkuliahan, kampus UII harus ditutup akibat agresi militer Belanda. Banyak mahasiswa dan dosen ikut berperang bersama tentara Indonesia untuk mengusir tentara Belanda. Informasi ini disebut dalam artikel "Sekilas UII" (dalam https://fk.uii.ac.id/sekilas-uii). Dalam kondisi perang, Abdul Kahar Muzakkir selaku Rektor pada masa itu sempat mengadakan Dies Natalies ke-IV, bertepat pada tanggal 27 Rajab 1368 (April 1949). Acara dilakukan bukan 
di area kampus UII, melainkan jauh dari pusat Kota Yogyakarta. Acara ini diadakan di Desa Tegalayang, Srandakan, Bantul. Dalam acara tersebut, selaku Rektor, Abdul Kahar Muzakkir menyampaikan sebuah pidato tentang Dasardasar Sosialisme dalam Islam. UII kemudian memindahkan aktivitas pembelajaran di beberapa daerah di Yogyakarta. Kraton Yogyakarta dan rumah dosen bahkan pernah menjadi ruang belajar mahasiswa UII (Pulungan, 2019: 360). Pada tahun 1950, aktivitas kampus mulai berjalan kembali secara normal setelah Indonesia bebas dari cengkraman Belanda.

\section{Dari Fakultas Agama UII menjadi PTAIN}

Pada waktu Pemerintahan Republik Indonesia berpusat di Yogyakarta, Yogyakarta dinobatkan sebagai kota universitas. Untukgolongan nasional, dibangun Universitas Gadja Mada (UGM). Untuk golongan Islam, dibangunkan Perguruan Tinggi Islam Negeri (Peraturan Pemerintah No. 34 Tahun 1950) yang diambil dari Fakultas Agama Universitas Islam Indonesia (Departemen Agama, 1996: 37). Pada saat itu, pemerintah juga sangat membutuhkan tenaga pekerja dalam bidang agama untuk mengisi berbagai jabatan yang ada di Kementerian Agama. Kementerian Agama kemudian memutuskan untuk merubah Fakultas Agama UII menjadi sebuah Perguruan Tinggi Agama Islam Negeri (PTAIN). Untuk Fakultas UII lainnya, statusnya tidak berubah. Melalui peraturan yang tertera sebelumnya dijelaskan bahwa secara resmi ditandatangani oleh Pemangku Jabatan Presiden RI tanggal 14 Agustus 1950. Namun secara resmi dibuka perguruan tinggi baru dengan nama PTAIN (Perguruan Tinggi Agama Islam Negeri) pada tanggal 26 September 1951 (Departemen Agama, 1996: 37).

Ketika Fakultas Agama UII menjadi PTAIN, UII pada saat itu hanya memiliki 3 Fakultas yakni Fakultas Hukum, Fakultas Pendidikan dan Fakultas Ekonomi. Seiring perkembangan waktu, ketika UII memasuki setengah abad, UII berhasil memiliki delapan Fakultas untuk program Strata Satu (S1) dengan 13 program studi, dua program studi tingkat S2, dan 3 program studi Diploma Tiga (D3). Sebanyak 15 tenaga pengajar tetap bergelar Doktor, 152 lulusan S2 dari dalam dan luar negeri. Sebanyak 71 orang sedang mengikuti program 
studi S2 dan sebanyak 30 orang sedang mengikuti program Doktor. UII berhasil menyelenggarakan pendidikan yang berwatak keilmuan, keislaman dan profesionalisme (Harjono \& Hakim, 1997).

\section{Penutup}

Berdasarkan studi di atas dapat disimpulkan bahwa Sekolah Tinggi Islam didirikan pada tanggal 8 Juli 1945. Pada awalnya STI didirikan di Jakarta. Abdul Kahar Muzakkir dipercaya sebagai Rektor STI. Banyak pemimpin Muslim memberikan kontribusi dalam pendirian dan pengembangan STI. Di antaranya Mohammad Hatta, A. Wahid Hasyim, K.H. Mas Mansyur, K.H. Fathurrahman Kafrawi dan Farid Ma'ruf. Akibat pendudukan Tentara Sekutu, STI dipindahkan ke Yogyakarta sebagaimana ibukota negara dipindahkan dari Jakarta ke Yogyakarta. STI, atas dukungan banyak pihak, menjadi lembaga pendidikan tinggi Islam yang berkembang pesat. Pada tanggal 10 Maret 1948, STI dikonversi menjadi UII dengan penambahan fakultas-fakultas baru. Sampai tahun 1948, UII mengelola empat fakultas yakni Fakultas Agama, Fakultas Ekonomi, Fakultas Pendidikan dan Fakultas Hukum. Lepas dari itu, studi ini masih merupakan sebuah tinjauan historis terhadap keberadaan STI. Menarik juga dilakukan tinjauan filosofis terhadap eksistensi STI, termasuk pemikiran-pemikiran pendidikan para tokoh yang mendirikan STI.

\section{Pustaka Acuan}

Ahmad, Munawar. (2010). Ijtihad politik Gus Dur: Analisis wacana kritis. LKiS.

Anwar Bachtiar, Tiar (2018). Lajur-lajur pemikiran Islam: Peta pergulatan intelektual Islam Indonesia abad ke-20 dan awal abad ke-21. JSP Publishing.

Daulay, Haidar Putra. (2006). Pendidikan Islam dalam sistem pendidikan nasional di Indonesia. Kencana.

Daulay, Haidar Putra. (2014). Sejarah pertumbuhan dan pembaharuan pendidikan Islam di Indonesia. Kencana.

Fathoni, Rifai Shodiq. (2018). Sejarah perguruan tinggi Islam di Indonesia. https://wawasansejarah.com, 15 September 2018. 
Islamijah: Journal of Islamic Social Sciences, Volume 1, Number 3, September 2020: 272-288

Harjono, Anwar dan Lukman Hakiem. (1997). Disekitar lahirnya republik: Bakti Sekolah Tinggi Islam dan Balai Muslimin Indonesia kepada bangsa. Dewan Dakwah Islamiyah Indonesia.

Ja'far, J. (2015). Tarekat dan gerakan sosial keagamaan shaykh hasan maksum. Teosofi: Jurnal Tasawuf dan Pemikiran Islam, 5(2), 269-293. https://doi.org/ 10.15642/teosofi.2015.5.2.269-293.

Ja'far, J. (2016). Peran Al Jam'iyatul Washliyah dalam merevitalisasi madhhab Shafi'i di era kontemporer. Justicia Islamica, 13(1), 1-29. https://doi.org/ 10.21154/justicia.v13i1.451.

Ja'far, J. (2019). Al Jam'iyatul Washliyah dan pelestarian akidah Ahl Sunnah wa al-Jamâ'ah di Indonesia. ISLAMICA: Jurnal Studi Keislaman, 14(1), 5481. https://doi.org/10.15642/islamica.2019.14.1.54-81.

Ja'far, J. (2020). Merantau demi republik: Kehidupan dan perjuangan Ismail Banda (1909-1951). Islamijah: Journal of Islamic Social Sciences, 1(2), 136161, http://dx.doi.org/10.30821/islamijah.v1i2.7181.

Ja'far, J. (2020). Tradisi intelektual ulama mandailing abad ke-20: Dedikasi dan karya-karya Yusuf Ahmad Lubis (1912-1980). Islamijah: Journal of Islamic Social Sciences, 1(3), 225-247, http://dx.doi.org/10.30821/islamijah.v1i3.7342.

Ja'far, J. (2020). Ulama Mandailing awal abad ke-20: Gerakan religius dan politik Abdurrahman Sjihab. Islamijah: Journal of Islamic Social Sciences, 1(1), 1-25. http://dx.doi.org/10.30821/islamijah.v1i1.7155.

Ja'far, J. (2020). Peran M. Arsjad Th. Lubis dalam pengembangan ilmu-ilmu keislaman. Dialogia: Jurnal Studi Islam dan Sosial, 18(2), 355-376, https:// doi.org/10.21154/dialogia.v18i2.2216.

Kahin, Audrey. (2005). Dari pemberontakan ke integrasi: Sumatera Barat dan politik Indonesia 1926-1998. Yayasan Obor Indonesia.

Kamil, Ediati. (1999). Kronik revolusi Indonesia. Gramedia.

Mochtar, Affandi (2003). Perguruan tinggi Islam di Indonesia: Sejarah pertumbuhan dan perkembangannya. Departemen Agama.

Nasution, S. (1995). Sejarah pendidikan Indonesia. Bumi Aksara. 
Nakamura, Mitsuo. (2019). Prof. H. Abdul Kahar Muzakkir dan perkembangan gerakan Islam Reformis di Indonesia. Afkaruna, 15(2), 203-225, https:// doi.org/10.18196/AIIJIS.2019.0103.203-225

Pulungan, Suyuthi. (2019). Sejarah pendidikan Islam. Kencana.

Salahuddin, Marwan. (2014). Model pengembangan pendidikan tinggi Islam di Indonesia. Ulumuna: Jurnal Studi Keislaman, 18(1), 121-138, https:// doi.org/10.20414/ujis.v18i1.155.

Tashadi. (1986). Prof. K.H. Abdul Kahar Muzakkir: Riwayat hidup dan perjuangannya. Departemen Pendidikan dan Kebudayaan.

Thaib, Hasballah dan Zamakasyari Hasballah. (2017). Mengenal almarhum alFadhil H. Adnan Lubis. Perdana Publishing.

Triyadi, Selamet. (2009). Modernisasi pendidikan Islam perspektif Prof. Dr. Azyumardi Azra, M.A. Undergraduate Thesis, IAIN Sunan Ampel Surabaya.

Universitas Islam Indonesia. http://www.almujtaba.com.

Sejarah singkat fakultas hukum UII. https://pascasarjanahukum.uii.ac.id.

Sejarah fakultas ilmu agama Islam. https://fis.uii.ac.id/sejarah.

Sekilas UII. https://fk.uii.ac.id/sekilas-uii.

Profil. https://www.uii.ac.id/profil. 